\title{
College Students' Attitude toward the Medium of Instruction: Arabic versus English Dilemma
}

\author{
Maha Ellili-Cherif ${ }^{1, *}$, Haitham Alkhateeb ${ }^{2}$ \\ ${ }^{1}$ College of Education, Qatar University, Qatar \\ ${ }^{2}$ Division of Science, Information Arts and Technologies; University of Baltimore, USA
}

Copyright $(\underset{0}{ } 2015$ Horizon Research Publishing All rights reserved.

\begin{abstract}
In 2012, the Supreme Education Council of the State of Qatar decreed a change from English to Arabic as a medium of instruction in four of the colleges of Qatar University. This surprise move created much controversy, especially among the students, the first stakeholders to be affected by this decision, related to the impact this change would have on their futures. The aim of this study is to investigate the attitudes of college students at Qatar University concerning the shift from English to Arabic as the language of instruction. The sample includes 295 students from the four colleges affected by this decision. Data were collected using an Arabic version of the standardized Student Attitudes Towards the Instructional Medium questionnaire. The findings of the study are interpreted in the light of students' perceptions about the place of English in Qatari society, the role of Arabic and English in their educational careers, and the importance of each language for their futures. Findings are also interpreted in the light of a review of previous findings on the attitudes of students on this issue. Discussion and recommendations may inform language policy decisions.
\end{abstract}

Keywords Language Policy and Planning, Student Attitudes, Medium of Instruction, Higher Education Curriculum and Instruction, Bilingualism

\section{Introduction}

In an attempt to meet the country's economic and social challenges, the Qatari government launched a comprehensive reform of the K-12 education system in 2001 . The country's leaders had become convinced that the education system was not producing high-quality outcomes and that it was rigid and outdated [11:3]. They contracted Rand Corporation, a non-profit research organization, to explore ways to build a modern, world-class education system capable of producing a populous that could fulfill the country's social and economic needs. The results of the investigation led to the launch of a reform initiative, Education for a New Era, which had the four major principles of autonomy, accountability, variety and choice.

One cornerstone of the reform was the introduction of English as the medium of instruction in K-12 mathematics and science classes. This decision was also applied at the level of higher education so that most majors offered at Qatar University (QU) would be taught in English. Most students seeking admission, however, did not meet the entry-level English proficiency scores required by most QU colleges. As a result, a Foundation Program was introduced to provide support in English and to improve students' proficiency levels so that they could access their chosen majors. The program had four levels, each lasting for one semester. After completion of the Foundation program, students were required to take an English proficiency test (International English Language Testing System or Test of English as a Foreign Language), yet many of them never managed to obtain the scores required by their majors and thus could not continue their educations. This caused much discontent and frustration among students as well as parents.

Other members of Qatari society also cried out against the use of English as a medium of instruction in K-12 and the university. The decision initiated frequent discussions within the community and in the media. While "policy makers have intrinsically linked development and modernization with English," [23, p338], other members of Qatari society considered this decision a threat to the mother tongue, local culture and national identity and a major cause for low achievement among students. For instance, in an Al-Sharq (local newspaper) article on June 5, 2010, Al-Sai questioned the rationale for teaching in a language that is not the mother tongue of the Qatari society. He claimed that teaching in English could devalue Arabic and lead to loss of self-identity. In an Al-Arab (local newspaper) article on May 21, 2012, Al-Shammari, the Academic vice principal of the boys Independent Secondary School for Commerce, strongly favored of the shift to Arabic as the medium of instruction in $\mathrm{K}-12$. He argued that the Qatari experience of teaching mathematics and science in English was a failure. He explained that the teachers were more concerned with 
improving the students' level of English than focusing on teaching content, which resulted in low achievement of the learners in the subject areas. At the opening of a Forum on the Advancement of Arabic Language held in Doha on May 29, 2012, Her Highness Sheikha Moza bint Nasser urged Arab academics and researchers to join efforts to give back Arabic language its prestigious and historic position as a language of science, culture and literature.

The decision to use Arabic as the medium of instruction at QU was made in June 2012. The Qatari Supreme Education Council decreed that Arabic would be Qatar University's official teaching language and that the faculties of law, international affairs, mass communication, and business and economics would shift to teaching in Arabic rather than teaching in English as they have done over the last decade [16]. While this decision might have been the result of pressure from the community, it was not supported by research studies.

Medium of instruction in the Arab region: the Arabic-versus-an-international language dilemma

The dilemma over whether use of Arabic or an international language as the medium of instruction is not limited to Qatar. Many other Arab countries have opted for using EMI in K-12 as well as in tertiary level education (e.g. UAE, Lebanon and Jordan); however such a policy has always faced much resistance. Discussions over the medium of instruction in the Arab world have raised tension among certain sections of the population. In a review of the literature on teaching science in Arabic, BouJaoude and Sayah [10] argued that discussions about the medium of instruction in the Arab world can be depicted in an ideological polemic between the "realism" of admitting the need to access scientific information through an international language and the "dream" about an Arabized science education that supports Arab academia to conduct research in Arabic.

Research-based studies on the medium of instruction in the Arab world tend to be rare; however, discussions over the issue in theoretical papers show that scholars tend to be divided in their opinions concerning the use of Arabic or an international language as the medium of instruction [8]. Some researchers argue for the importance of the foreign language as a means to access modern ideas and technological innovations. They argue that an international language, English more specifically, is a benefit to the students and that high proficiency in English is a requirement in the job market [8].

Other scholars acclaim the importance of the use of Arabic as a basis for national and regional identities. They argue that it is preferable to teach in the mother tongue for social and pedagogic reasons $[5,9,24,18,7]$. Arabic is the language of the Holy Quran and the vehicle of Islamic culture. Being the language of literary expression, Arabic is considered a means to contribute to the preservation of Arab unity and to cement the Arab community $[9,3,14]$.

BouJaoude and Sayah [10] indicated that a review of the research on teaching science in native and non-native languages outside Arab countries points to the pedagogic benefits of teaching science in the mother tongue; however, they cautioned against the generalization of the results of such studies to the Arab context and suggested that scholars resist the implication that science must be taught in Arabic in the Arab world. They suggested that further research should be conducted to evaluate the effectiveness of the Arabization of science education.

Al-Qurashi [6] investigated Saudi Arabian educational institutions to elicit specific information on participants' awareness and attitudes about Arabization and the educational impact of the Arabization process. Results showed that the respondents did not dispute the richness and capability of the Arabic language as a medium of instruction. They contended that the use of a foreign language in imparting education was a major obstacle for some students and contributed to a high drop-out rate.

While scholars seem to be divided in their opinions about the role and importance of Arabic as a medium of instruction, other stakeholders, such as parents, tend to be more in favor of the Arabization process. The resistance to the use of an international language in imparting education is noticeable among parents in Arab countries. For instance, in a study investigating teachers' principals' and parents' attitudes to the educational reform in Qatar, parents thought one major disadvantage of the reform is that teaching science and math in English is a major threat to the national identity $[12,21]$. Al-Harthi [2] also investigated parents' perceptions of the impact of bilingual education on their children. The study revealed that in addition to pronunciation problems in Arabic, a more dangerous perceived impact is the spread of Western cultural values and ethics that are contrary to the local culture, so much so the students are losing their identity. The study concludes that the natural result of bilingual education is the replacement of the mother tongue by the second language and of the local culture by the culture of the target language.

Research studies investigating student attitudes toward the use of Arabic as a medium of instruction in Arab countries are rare. Existing studies point to some students supporting of the use of Arabic as the language of instruction while other studies show that they are in favor of English as a medium of instruction. For instance, Al-Muhaidab [5] found that students in several Arab universities were in favor of studying in Arabic because it is easier to learn in their mother tongue. Other studies investigating students' attitude to English and its use as a medium of instruction in post-secondary schooling in Kuwait [17] and the UAE [25] point to an overall positive attitude to EMI. Al-Jaraf [4] investigated students' perception of the importance of Arabic and its use as a medium of instruction at tertiary level in two Jordanian universities and reached contradicting results. Her study showed that most students value English more highly than Arabic. They think that Arabic is a poor language compared to English, when it comes to usefulness in accessing resources, databases and research. English is thought to be a superior language because it is the language of science, business and technology. As for the students' opinions about the use of Arabic as a medium of instruction, the majority of respondents believe that Arabic should be 
used in teaching Islamic studies and arts majors such as Arabic literature and history, while they strongly believe that English should be the language of instruction in majors like medicine, engineering and computer sciences. Hence, the research indicates that there is no single opinion among scholars about the language to be used for instruction in Arab educational contexts; neither is there clarity regarding students' opinions about this issue.

In Qatar, the shift to Arabic-instructed education at university level was based on a decision by Qatar's educational authorities that the country's leading public university should revert to Arabic as its language of instruction as a validation of student's mother tongue [16]. No studies have been carried out on the attitudes of university students towards the instructional language in the leading public national university in Qatar. This study aims to assess students' attitudes towards the medium of instruction at Qatar University. The main purpose is to provide empirical data and psychometric properties of an Arabic version of the Student Attitudes Towards the Instructional Medium, including the factor structure and the internal consistency reliability of the questionnaire. Another objective was to assess, through descriptive analysis, what a sample of Arab undergraduate university students in the State of Qatar think about the shift to Arabic as the language of instruction.

\section{Method}

Sample

The sample of this study consisted of 295 university students from College of Law (23.4\%), College of Business and Economics (23.7\%), Department of Mass Communication (29.5\%), and Department of International Affairs (23.4\%). Students' views on the use of Arabic language as a medium of instruction in their program of study were solicited. The ages of the students ranged from 18 to 40 years, with a mean of 21.6 years $(\mathrm{SD}=2.4)$. The majority of the participants were female $(83.1 \%)$, a figure similar to the student population in the university (about $70 \%$ female) that this sample represents.

\section{Instrumentation}

The instrument used in this study consisted of three parts. Part one dealt with student demographic information (nationality, gender, age, etc.). Part two dealt with general information about the medium of instruction in the students' educational contexts before joining the university. Part three was the questionnaire, Student Attitudes Towards the Instructional Medium [26], containing four factors and 33 items in total that required respondents to rate a given statement according to a 5-point Likert-type scale, ranging from never or only rarely (1) to always or almost always (5). This part determined the respondents' overt responses to individual items measuring students' attitudes towards the shift to Arabic as the language of instruction. The questionnaire was distributed in different classes towards the end of the fall semester, eleven months after the university had shifted to Arabic as the medium of instruction.

The questionnaire was translated from English to Arabic. Although a formal back translation was not performed, several native speakers of Arabic agreed that the translation was adequate. Some terms were replaced in the questionnaire to make it context appropriate. Chinese in the original questionnaire was changed to Arabic, Secondary School to University, Forms 1-3 (Grades 7-9) to University Core Courses, Hong Kong to Qatar, and Form 4 (Grade 10) to Major Courses. The four factors of the questionnaire were "Arabic is a more efficient and effective language for learning" (Factor I); "English is a language for careers" (Factor II); "All students should be allowed to study through English" (Factor III) and "Arabic can be used to help students learn in English" (Factor IV).

\section{Results}

Two methods of analysis were used in this study in response to the research questions. The first method concerns the participants' views on particular issues described by means and standard deviations of their responses to the items. These measures are presented in Table 1 . Table 2 presents a summary view of the responses for the four factors in terms of means and standard deviations of their responses. The second method relates to the underlying factors determining participants' overt responses to individual items; therefore, factor analysis was used to assess the factors of the questionnaire. To decide on the number of factors to examine, the conventional criterion of only admitting factors with eigenvalues greater than one was used. An oblique solution resulted. Table 3 gives the intercorrelation of the four factors of the questionnaire.

Table 1 contains the means and standard deviations of the questionnaire items. Each statement was rated by the students as in the original study, such that "1" meant, "This statement never or only rarely describes accurately my thinking and behavior, "2" meant, "This statement sometimes describes accurately my thinking and behavior, " 3 "meant, "This statement describes accurately my thinking and behavior about half the time, " 4 " meant, "This statement frequently describes accurately my thinking and behavior, and "5" meant, "This statement always or almost always describes accurately my thinking and behavior." Table 1 indicates that the student responses can be analyzed into four correlated factors. Students agree that Arabic is a more efficient and effective language for learning (Factor I). They also agree that English is a language for careers (Factor II). Factor III indicates that all students should be allowed to study through English. Nevertheless, students feel that Arabic can be used to help students to learn in English (Factor IV). Factor I consists of items 3, 22, 6, 4, 2, 25, 1, 14, $23,32,17,19,18$, and 26. Factor II consists of items 24, 31, 10, 28, 5, 29, 11, 16, and 20. Factor III consists of items 7, 27, and 15. Factor IV consists of items 33, 8, 21, 9, 13, 30, and 12. 
Table 1. Mean and Standard Deviation of Student Responses to the Questionnaire

\begin{tabular}{|c|c|c|c|}
\hline \# & Item & $M$ & $S D$ \\
\hline 1 & I think the greatest difficulty in using English to study is learning a great many new words. & 3.32 & 1.41 \\
\hline 2 & $\begin{array}{l}\text { I am more motivated when I use Arabic (and not English) to study non-language subjects (e.g., } \\
\text { Mathematics, Science, Geography, and History). }\end{array}$ & 3.15 & 1.57 \\
\hline 3 & I can obtain higher marks answering examination questions in Arabic. & 3.37 & 1.41 \\
\hline 4 & I feel that I can write better in Arabic than in English. & 3.34 & 1.53 \\
\hline 5 & I feel that studying all subjects in Arabic will lower the standard of my English. & 3.51 & 1.28 \\
\hline 6 & I feel that I can save a lot of time studying all subjects in Arabic rather than in English. & 3.20 & 1.53 \\
\hline 7 & I feel that it is more difficult to learn special terminology in Arabic than in English. & 2.85 & 1.46 \\
\hline 8 & $\begin{array}{l}\text { Teachers should use Arabic as the main medium of instruction at the beginning of term, gradually } \\
\text { increasing the use of English as a medium of instruction, so that students can get used to studying in } \\
\text { English step by step. }\end{array}$ & 3.24 & 1.38 \\
\hline 9 & I feel that the teacher's method of teaching is more important than the medium $\mathrm{s} / \mathrm{he}$ uses for instruction. & 3.79 & 1.24 \\
\hline 10 & I feel English has a higher status than Arabic in Qatar at present. & 3.87 & 1.21 \\
\hline 11 & I believe my parents would like me to study all subjects in English. & 3.11 & 1.32 \\
\hline 12 & We communicate in Arabic in our everyday life, so we should study in Arabic. & 3.09 & 1.38 \\
\hline 13 & I feel that learning Arabic well will help me to learn English well. & 2.99 & 1.23 \\
\hline 14 & $\begin{array}{l}\text { Problems of learning are created if Arabic is the instructional language in the primary school while } \\
\text { English is the instructional language in the university. }\end{array}$ & 3.80 & 1.36 \\
\hline 15 & $\begin{array}{c}\text { I feel that high-achieving students should study English, while low-achieving students should study in } \\
\text { Arabic. }\end{array}$ & 2.68 & 1.33 \\
\hline 16 & I think that all the university students in Qatar should study all subjects in English. & 2.99 & 1.21 \\
\hline 17 & I support adopting mother-tongue education in the university where I study. & 3.21 & 1.51 \\
\hline 18 & If I study every subject in Arabic, my family members can give me more help. & 3.03 & 1.43 \\
\hline 19 & I believe Arabic should be the medium of instruction for the university core courses. & 3.24 & 1.52 \\
\hline 20 & I think English should be the medium of instruction for the university major courses. & 3.10 & 1.35 \\
\hline 21 & $\begin{array}{l}\text { I feel that teachers using both English and Arabic within the same lesson can facilitate students' } \\
\text { learning of the contents of each subject. }\end{array}$ & 3.56 & 1.36 \\
\hline 22 & I obtain better results in subjects that I study in Arabic than the ones I study in English. & 3.18 & 1.42 \\
\hline 23 & My teachers think that I can achieve better results if I study all subjects in Arabic rather than in English. & 2.78 & 1.23 \\
\hline 24 & I think learning English well is more important than learning Arabic well. & 2.86 & 1.29 \\
\hline 25 & I can spend less time on my studies if I study all subjects in Arabic rather than in English. & 3.18 & 1.49 \\
\hline 26 & $\begin{array}{c}\text { I think that the majority of universities in Qatar should adopt mother-tongue education in one or two } \\
\text { years. }\end{array}$ & 3.04 & 1.44 \\
\hline 27 & $\begin{array}{l}\text { I think the great majority of the universities in Qatar should gradually adopt Arabic as the medium of } \\
\text { instruction within the next five to ten years. }\end{array}$ & 3.19 & 1.26 \\
\hline 28 & $\begin{array}{l}\text { I think the great majority of the universities in Qatar should still use English as a medium of instruction } \\
\text { within the next five to ten years. }\end{array}$ & 3.32 & 1.31 \\
\hline 29 & I feel that studying all subjects in English will help raise the standard of my English. & 3.79 & 1.19 \\
\hline 30 & I feel that studying all subjects in Arabic will help raise the standard of my Arabic. & 3.48 & 1.25 \\
\hline 31 & $\begin{array}{l}\text { I think using Arabic to study all subjects will affect my chances for further studies after graduation } \\
\text { from the university. }\end{array}$ & 3.51 & 1.34 \\
\hline 32 & If the teacher teaches in Arabic, the classroom atmosphere would be more conductive to learning. & 2.96 & 1.38 \\
\hline 33 & I feel that my abilities in Arabic and English are mutually reinforcing. & 3.49 & 1.13 \\
\hline
\end{tabular}

The results of internal consistency analyses of the four factors of Student Attitudes Towards the Instructional Medium were 0.94, 0.75, 0.54, and 0.72 for Factors I, II, III, $\&$ IV, respectively. Items were combined into a factor score by summing the related item score for each factor. The four factor scores were thus described by summing the fourteen items composing the factor, "Arabic is a more efficient and effective language for learning," summing up the nine items making the factor, "English is a language for careers," summing the three items composing the factor "All students should be allowed to study through English," and summing the seven items composing the factor, "Arabic can be used to help students to learn in English." Henson [15] indicated that a value of .54 may be rather low. It is noted here that this factor consists of only three items, which explains the low reliability for this factor. 
To validate the factor structure of the instrument, the correlation matrix was analyzed by principal components factor analysis with oblique direct oblimin and delta $(\delta)$ set at zero. This kind of rotation is appropriate because it is theoretically and empirically accurate [13]. It is also suitable for factors that are related to each other compared to the orthogonal rotation, which is considered more appropriate if the factors were independent [19]. Employing the general and accepted factor extraction (Kaiser-Gutman rule of 1.0 as the minimum eigenvalue, and Catell's scree test), six factors had eigenvalues greater than 1.0 were extracted. They successively accounted for $10.6 \%, 4.1 \%, 2.0 \%, 1.6 \%, 1.4 \%$, and $1.0 \%$ of the total variance of the questionnaire. Rotation of factor analysis indicated a solution of four factors, which is the required number of factors in the screen test solution. They accounted for $55.3 \%$ of the variance. Extracting more than four factors produces factors with insignificant variable loadings. The resulting factor structure generally supported the factors that the Student Attitudes Towards the Instructional Medium was designed to measure. In general, the factor loadings report high factor loadings for each variable. Most of the loadings were above 0.30 , and the loadings generally low on the other factors they are not designed to measure.

Tables 1 and 2 indicate that students agree that both languages, Arabic and English, are useful and valued languages for them. The four items of Factor 1 that students identified most with were "Problems of learning are created if Arabic is the instructional language in the school while English is the instructional language in the university" (mean $=3.80$, where $5=$ statement describes student's thinking and behavior always or almost always), item "I can obtain higher marks answering examination questions in Arabic" (mean = 3.37), item "I feel that I can write better in Arabic than in English" (mean = 3.34), and item "I think the greatest difficulty in using English to study is learning a great many new words" (mean $=3.32)$. Students, however, agree that English is important for their careers (Factor II). The four items that students assent to most were item "I think using Arabic to study all subjects will affect my chances for further studies after graduation from the university" (mean $=3.51$ ), item "I feel English has a higher status than Arabic in Qatar at present" (mean $=3.87)$, item "I feel that studying all subjects in Arabic will lower the standard of my English" (mean $=3.51)$, and item "I feel that studying all subjects in English will help raise the standard of my English" (mean = 3.79). Factor III indicates that the students feel that everyone should be given the opportunity to study in English. For example, they "feel that it is more difficult to learn special terminology in Arabic than in English" (mean = 2.85). Moreover, students feel that Arabic can be used to help them to learn in English (Factor IV). The two items that are most representative of their thinking on this factor were item "I feel that teachers using both English and Arabic within the same lesson can facilitate students' learning of the contents of each subject" (mean = 3.56), and item "I feel that the teacher's method of teaching is more important than the medium s/he uses for instruction" (mean $=3.79$ ).

Table 2. Analysis of Student Attitudes Towards the Instructional Medium into the Four Factors

\begin{tabular}{lcc}
\hline \multicolumn{1}{c}{ Factor } & Mean & SD \\
\hline $\begin{array}{l}\text { I. Arabic is a more efficient and effective language for } \\
\text { learning }\end{array}$ & 3.20 & 1.1 \\
\hline II. English is a language for careers & 3.34 & 0.84 \\
\hline $\begin{array}{l}\text { III. All students should be allowed to study through } \\
\text { English }\end{array}$ & 2.91 & 0.83 \\
\hline $\begin{array}{l}\text { IV. Arabic can be used to help students to learn in } \\
\text { English }\end{array}$ & 3.38 & 0.78 \\
\hline
\end{tabular}

As shown in Table 3, Factors II and III correlate the highest, suggesting that students view studying through English as a means to careers. Factors I and IV are also significantly correlated, but negatively. This negative correlation suggests that students view Arabic as an efficient and effective language for learning, but do not believe it helps them to learn in English.

Table 3. Intercorrelations Among Student Attitude Factors

\begin{tabular}{llll}
\hline & Factor I & Factor II & Factor III \\
\hline Factor II & $-.32 * *$ & & \\
\hline Factor III & -.06 & $.35 * *$ & \\
\hline Factor IV & $-.53 * *$ & -.05 & .05 \\
\hline
\end{tabular}

**. Correlation is significant at the 0.01 level (2-tailed).

Students in this study are clearly supportive of teachers using both English and Arabic in the same class (item: I feel that teachers using both English and Arabic within the same lesson can facilitate students' learning of the contents of each subject, mean $=3.56$ ). Students also do not see a significant relationship between learning Arabic well and learning English well (Item: I feel that learning Arabic well will help me to learn English well, mean $=2.99$ ), although they tend to agree that their Arabic and English abilities are mutually reinforcing (Item: I feel that my abilities in Arabic and English are mutually reinforcing, mean $=3.49$ ). Favoring allowing all students to study in English (Factor III, Table 2) was rated the lowest when compared with the three other factors, considering Arabic is their first language. They marginally disagree with the proposal that high-achieving students should study in English, while low-achieving students should study in Arabic (Item: I feel that high-achieving students should study English, while low-achieving students should study in Arabic, mean = 2.68).

The above results may make it easier to understand students' answers on statements related the changes in the medium of instruction, such as the item "I support adopting mother-tongue education at the school where I study" (mean $=3.21$ ). Students are also sympathetic towards using Arabic as a medium of instruction in the university core courses, as shown in the results to the statement, "I believe Arabic 
should be the medium of instruction for the university core courses" (mean $=3.24)$. Students had a strong belief that English has high status compared to Arabic at the present time (Item: I feel English has a higher status than Arabic in Qatar at present, mean $=3.87$ ).

\section{Discussion}

The findings of this study are not surprising and seem to confirm the results of other investigations of Arab students' opinions about the use of Arabic as a medium of instruction [see 10, 4, 5]. Students think that Arabic should be the language of instruction. This view may be due to the fact that most of the respondents in this study might not have the high level of English needed to be successful if their higher education studies were to be in English. In fact, the results of national and international tests indicate that students' level of English is low. In the 2009 PISA report [20], Qatar ranked 61 out of 65 participating countries, and scored statistically significantly below the OECD average. The results of the national assessment tests show that only $8 \%$ to $15 \%$ of students in all grades meet standards in English [22]. Moreover, the implementation of bilingual education in $\mathrm{K}-12$ was hindered by several issues, such as the difficulty to recruit highly qualified subject content teachers who have a good command of English. From the researchers' experience as instructors in a teacher education program, they can attest to the challenges that teachers are facing in teaching content courses in English [11]. Many of these practitioners were required by their schools to take English courses in the British Council to improve their English proficiency level. The fact that students might not have been properly equipped with English language skills at the K-12 level might be the reason they prefer to study in Arabic at tertiary level.

Nevertheless, most respondents tend to highly value English. They agree that English has high status in Qatari society and that low proficiency in English will certainly affect their future job prospects and employability. This attitude can be explained by the importance of this language for their higher educational studies and their job prospects. Like students in other studies in Arab countries, they are aware of the importance of English for their future careers. In the era of globalization, many careers in business, media and international affairs do not only require a deep understanding of how things work in the West, but also high proficiency in English. In addition, most institutions in the Qatari job market require that candidates be versed in English. In a study investigating the needs of English by graduates of Qatar University in the workplace, Al-Buainain et.al. [1] found that more than $77 \%$ of this workforce needs to use English at varying degrees. This raises the important question about the chances the students will have of finding a job inside or outside of Qatar after graduation. In addition to the problems the shift to Arabic as a medium of instruction poses for the job prospects of future graduates, students might be aware of the fact that this move might also affect their educational careers. References for most subjects are only available in English. Also, most textbooks in the curriculum of international affairs, media and business studies are in English; therefore, it would be very difficult to conduct authentic research. There is also a limitation on the students' chances of engaging in post-graduate studies since most of those programs, not only abroad but also in Qatar, are offered in English and require mastery of the English language.

Another explanation might be the influence of their parents' opinions that English is a threat to the local language and culture. Research studies have pointed to the parents' resistance to the use of English as a medium of instruction and their preference for the Arabization of the education system in Qatar. Parents' low proficiency in English might be another reason students prefer to study in Arabic. Responses indicate that many students admitted that if they study every subject in Arabic, their family members could provide more help.

In summary, the results clearly indicate that students think that using Arabic enhances their learning, but at the same time, they agree that the move will affect their job prospects and their chances of completing post-graduate studies. This ambivalent attitude was not totally unpredicted. Students' K-12 experience of bilingual education did not adequately prepare them to succeed in a college education in which the language of instruction is English. Even though they were taught English as a second language for five hours per week and were taught math and science in English, they still preferred to be taught in Arabic at university level and thought that Arabic as the language of instruction would enable them to be more successful in their studies than if the language of instruction is English.

\section{Conclusions}

After ten years of English mediated instruction, the decision to shift from English to Arabic as a medium of instruction in the colleges of business, mass communication, law and international affairs in Qatar University was a surprising move. There was much controversy from different stakeholders between supporters and antagonists of the shift; however, students' voice on this issue was not taken into account. This research set out to investigate students' attitudes toward the use of Arabic as a medium of instruction. The results point to a contradiction in the respondents' opinions favoring mother tongue instruction in spite of an awareness that this would jeopardize their employment chances and future studies. This ambivalence is further supported by the clear view that English has a high status in Qatar. These findings support the SEC's decision to return to Arabic-mediated-instruction; however, the university, and more specifically the colleges affected by this decision, need to take measures to ensure that students' English proficiency levels at graduation enables them to meet the requirements of the job market. One way this can be achieved is to offer 
English for Specific Purposes courses that help to improve students' English skills to levels that match the employment or further education requirements of their disciplines. Another option would be to offer Arabic and English tracks in the majors. Students would then have the choice to select the language that best meets their educational needs.

\section{REFERENCES}

[1] Al-Buainain A H, Hassan F K, Madani A. Needs of English by graduates of Qatar University in the workplace. The International Journal - Language Society and Culture [Internet]. 2010 [cited 2013 Sept 06]; Issue 31:18-27. Available from: www.educ.utas.edu.au/users/tle/JOURNAL/.

[2] Al-Harthi I. The impact of bilingual education on the mother tongue (Author translation from Arabic). The Jordan Academy of Arabic [Internet]. 2011 [cited 2013 Sept 09]. Available from: http://www.majma.org.jo/majma/index.php/ 2009-02-10-09-35-28/466-2012-04-23-07-35-32.html

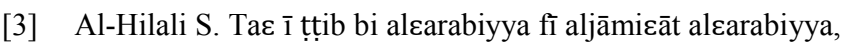
in Shozun Earabiyya, No 47; 1986 Sept.

[4] Al-Jaraf R. College students' attitudes towards using English and Arabic as a medium of instruction at the university level (Author translation from Arabic). Diwan Al-Arab: Manbar Horr li Thakafa Waladab [Internet]. 2004 [cited 2013 Jun 24]. Available from:

http://www.diwanalarab.com/spip.php?article748

[5] Al-Muhaideb A B I. Ta3rib Atta3lim Al-handasi fi Al-mamlaka Al-Arabiya Assa3oudia: Al-wa9a3 we Al-amal. Beirut, Lebanon: Arabic Unit Center Studies; 2005.

[6] Al-Qurashi K O A. The feasibility of the Arabic language as a medium of instruction in sciences. Indiana University, ProQuest, UMI Dissertations Publishing; 1982. 8301092.

[7] Al-Tatawi A. Ahamiyat Ata3lim Bilughati Al3arabiya. 2013 [cited 2013 Dec 03]. Available from : http://www.khayma.com/madina/m2-files/arabic-tec.htm

[8] Amin T G. Language of instruction and science education in the Arab World: Toward a situated research agenda. In: BouJaoude S and Dagher Z. editors. The World of Science Education: Arab States. Rotterdam, The Netherlands: Sense Publishers; 2009. p. 61-82.

[9] Benkharafa M. (2013). The present situation of the Arabic language and the Arab world commitment to arabization. Theory and Practice in Language Studies. 2013; 3(2): 201-208.

[10] BouJaoude S, Sayah F. Teaching science in Arabic: Attitudes and solutions. In Shaaban K, editor. Language and Education Beirut: Lebanese Association for Educational Studies; 2000. p. 145-169.

[11] Brewer D, Augustine C, Zellman G, Ryan, G, Goldman, C, Stasz C, Constant, L. Education for a new era design and implementation of K-12 education reform in Qatar. Santa Monica CA: Rand Corporation; 2007.

[12] Ellili Cherif M, Romanowski M H. 2013. Education for a New Era: Stakeholders' Perception of Qatari Education
Reform. International Journal of Education Policy and Leadership. 2013; 8(6):1-17.

[13] Hair J F Jr, Anderson R E, Tatham R L. Multivariate data analysis with readings (2nd ed.). New York: Macmillan; 1987.

[14] Hamdaoui J. Allugha Al3arabiya wa Tadris Al3ouloum. Diwan Al-Arab: Manbar Horr li Thakafa Waladab [Internet]. 2002 [cited 2013 Sept 13]. Available from http://www.diwanalarab.com/spip.php?article7094

[15] Henson R. K. Understanding internal consistency reliability estimates: A conceptual primer on coefficient alpha. Measurement and Evaluation in Counseling and Development. 2001 Oct; 34(3): 177-189.

[16] Lindsey U. (2012, February 7). Debate arises at Qatar University over decision to teach mainly in Arabic. The Chronicle of Higher Education [Internet]. 2012 Feb [cited 2013 Feb 26]. Available from http://chronicle.com/article/Debate-Arises-at-Qatar-U-Over/ 130695/

[17] Malallah S. English in an Arabic environment: Current attitudes to English among Kuwait university students. International Journal of Bilingual Education and Bilingualism. 2000 July; 3(1): 19-43.

[18] Mohamedani A A, Abdul Rahman S H, Al-Abbass O S T. A critical view of Arabic curriculum as a requirement for medical schools. Eastern Mediterranean Health Journal. 2009; 15(1):198-208

[19] Norman G R, Streiner D L. Biostatistics: the bare essentials (3rd ed.). Lewinston, New York: BC Decker Inc. 2008 .

[20] OECD (2010), PISA 2009 Results: Executive Summary [Internet]. 2010 [cited 2012 Aug 03]Available from http://www.oecd.org/pisa/pisaproducts/46619703.pdf

[21] Romanowski M H, Ellili Cherif M, Al Ammari B, Al Attiyah A. Qatar's Educational Reform: The Experiences and Perceptions of Principals, Teachers and Parents. International Journal of Education. 2013 Aug; 5(3):108-135.

[22] Supreme Education Council website . 2009 [cited 2013 Jan 15]. Available from

http://www.sec.gov.qa/En/Media/News/Pages/NewsDetails.a spx?NewsID $=2892$

[23] Syed Z. TESOL in the Gulf: The Sociocultural Context of English Language Teaching in the Gulf. TESOL Quarterly. 2003 Summer; 37(2): 337-341.

[24] Taha S O, Taha H O, Abdelbagi O M, Mohamedani A A. The Situation of Arabicization in the University of Gezira Faculties of Health Sciences after a Decade and a Half. Gezira Journal of Health Sciences. 2012; 8(2):57- 70.

[25] Troudi S. Jendli A. Emirati students experiences of English as a medium of instruction. In Al-Issa A. Dahan L S, editors. Global English and Arabic: Issues of language, culture and identify. Oxford: Peter Lang; 2011. p. 23-48.

[26] Tung P, Lam R, Tsang W. English as a medium of instruction in post-1997 Hong Kong: What students, teachers, and parents think. Journal of Pragmatics. 1997; 28(4):441-459. 